\title{
COTIDIANO
}

\section{PÓS-MODERNIDADE E JUVENTUDE}

\section{Manuel José Pina Fernandes(1)}

Não se pode falar em Pós-Modernidade sem antes se falar em Modernidade. É um imperativo cronológico, senão uma questão de raciocínio histórico e lógico.

Falar em Modernidade implica, para nós, retroceder um pouco no tempo histórico e muito mais que isso, implica também determinar, em relação a que se está falando. Assim, por exemplo, essa Modernidade, no que diz respeito à imprensa, tem suas raízes lá no séc XV quando Gutenberg a cria, em 1455. Por outro lado, podemos dizer que a Modernidade começa, meio século depois, em 1517, quando a Reforma Protestante dá origem ao Renascimento. Na política é Maquiavel, com “O Príncipe”, quem instaura a modernidade. A Filosofia, para Descartes, deveria ter como objeto de estudo aquilo que a razão apreende com nitidez e clareza. Para ele, pela objetividade dessa razão, se poderia captar a dimensão mensurável da verdade.

O existencialismo, de quem muitos dizem que Søren Kierkegaard é o pai, prevê que a vida humana é movida por suas paixões, logo, não pode ser movida nem reduzida a elementos biológicos ou à simples atividade intelectual, mesmo que rudimentarmente. Jean Paul Sartre afirmava que os homens precisavam dar um sentido à vida. Mas esse sentido tinha que ser criado pelo próprio homem. O existencialista vive voltado para si mesmo porque o relacionamento com seus semelhantes lhe causa "náuseas",. Portanto, é a partir da sua individualidade que o existencialista passa a criar um sentido para a vida, o seu "ser ou seu nada"ii.

Por outro lado, F. Nietzche, tenta transformar o ser humano em "super-homem" capaz de se contrapor ao que ele mesmo vai chamar de absurdo e incoerência da existência humana.

Digamos que alguns homens acreditam na existência de um Deus e outros não. Lá, na Modernidade, podia-se escutar alguém dizer: "Deus está morto". Hoje, na Pós-Modernidade, 
que tem como característica muito forte a crise de identidade, há quem diga: "Karl Marx também está morto". Cada qual acredita no que lhe convém.

Falamos em crise de identidade, mas, como ela surge, como ela nos atinge e a que ela pode levar-nos?

A crise de identidade deve ser vista como uma das partes componentes de um processo bem amplo de mudanças. Essas mudanças estão deslocando as estruturas e os processos centrais de reconhecimento das sociedades que se instalaram na Modernidade e, ao mesmo tempo, abalando fortemente as referências que davam ao ser humano um porto seguro para uma ancoragem estável e tranqüila no mundo social.

A crise de identidade é sintomática. Percebemos que ela nos atingiu quando nos damos conta do declínio das velhas identidades que se pautavam nos paradigmas das classes, do gênero, da sexualidade, da etnia e da nacionalidade que eram a marca maior da estabilidade e solidez do homem no mundo social em que ele estava inserido. A crise de identidade traz-nos a estratificação, a fragmentação do indivíduo, do ser social. O homem perde o sentido de si e acontece aquilo a que podemos chamar de deslocamento do homem, em si e no mundo, da centralidade que ele tinha ao longo do Iluminismo. Ali, no Iluminismo, o homem era visto como sujeito integrado, que depois passa a sujeito psicológico e, por último a sujeito sociológico. Era a evolução do sujeito. Daquele homem individualista, centrado, agindo racionalmente, começa a surgir o homem sociológico, aquele que passa a reconhecer outros "eus", através dos quais passa a poder medir valores, símbolos e sentidos na sua existência.

Na Pós-Modernidade surge, então, esse outro homem: fragmentado, sem identidade fixa, que se vai formando e transformando de forma contínua, em virtude das relações que estabelece e das formas como é representado e interpelado nos e pelos sistemas sócioculturais em que se localiza.

A nossa identidade passa por diversos estágios de identificação e não é algo inato, muito pelo contrário, ela é resultado de uma elaboração discursiva durante a qual se constrói uma narrativa do "eu". Portanto, podemos afirmar que são as referências, quem pode contribuir para a criação dessa identidade pessoal. Essas referências podem ser de qualquer tipo: religiosas, políticas, culturais, valorativas, normativas etc., mas, ao perdê-las, para adentrarmos e sermos reconhecidos na aldeia global, estamos, nós também, perdendo pouco a pouco a nossa identidade anterior, para tentarmos reconstruir uma outra que pode ser apenas temporária. Para alguns pensadores, os extremos das identidades podem substituir o local pelo global e vice-versa. E nós diríamos que, nos dias de hoje, para se ser aceito pela sociedade http://idonline.no.comunidades.net 
globalizada, é necessário interiorizar o global, o que provoca, em curto prazo, a falência das identidades modernas. Somos hoje mais provisórios, mais temporários, mais mutantes e problemáticos nas crises de identidade ou existenciais. Identidades essas, quantas vezes contraditórias ou não bem resolvidas.

A Pós-Modernidade, de quem não se tem como determinar o momento exato de seu surgimento, tem trazido, principalmente à nossa juventude, uma problemática para a qual ela ainda não está preparada para resolver. Repare-se que quando dizemos juventude, não nos estamos referindo apenas a esta que aqui se encontra diante de nós, não, referimo-nos à juventude, ao tempo em que ela existe para qualquer ser humano. Por outras palavras e exemplificando: na nossa juventude, esses problemas já existiam, muito embora em quantidades menores - pelo menos assim pensávamos -mas estavam ali, a nos deixarem perplexos diante das situações até então desconhecidas: Os Beatles e seus cabelos longos; os primeiros hippies com seu lema “amor, drogas e Rock'n roll”. Por esse tempo, até o superhomem foi eliminado por um robô. Mas ele voltaria, pois ele apenas estava recarregando suas energias que a Kryptonita lhe havia roubado. E o homem-aranha? Coitado! Descobria que não passa de um clone, pois o verdadeiro não estava mais em ação! Percebemos que até os superheróis, de tempos a outros, passam a praticar atos menos dignos à sua imagem, atos antiéticos, originados por problemas de identidade. Na Pós-Modernidade não se sabe mais quem é quem! Ou melhor, na Pós-Modernidade, dependendo dos interesses, cada um incorpora a identidade que mais lhe é conveniente para o momento que vivencia. Senão vejamos:

Quantos de nossos jovens, ou até nós mesmos, pacatos e ordeiros por princípio, não assumimos posturas que nos identificam de outro modo, de acordo com a nossa "galera", apenas por mera conveniência? Quantos de nós não entramos em lutas que são de outros, apenas para garantirmos aquilo que julgamos ser nosso por direito, mesmo sabendo que com isso estamos usurpando os direitos de outros que, muitas vezes, estão lutando do nosso lado? Quantos de nossos jovens, apenas para manterem ou afirmarem a sua pós-modernidade, não enveredam pelo caminho das drogas, pois, não o fazer é sinal de cafonice? E a banalização desenfreada do sexo?

O que o homem não é capaz de fazer para se auto-afirmar: som do carro nas alturas, "pegas" nas ruas da cidade, aquele "roubo" do carro do papai, o álcool e o fumo em idade imprópria?

É essa a Pós-Modernidade? A insensibilidade e a insensatez aos apelos paternos, o desajuste de regras às condições de cada um? E tudo isto em nome da pior das chagas que a humanidade já suportou - o capitalismo. 
(1) Manuel J. Pina Fernandes é Mestre em Educação e Professor da Universidade Regional do Cariri URCA, Crato-CE. (mjpf_ce@yahoo.com.br) 